\title{
POLIO CHRONICLES: WARM SPRINGS AND DISABILITY POLITICS IN THE 1930s
}

\author{
Naomi Rogers
}

Yale University

\begin{abstract}
During the 1920s and 1930s, disabled polio survivors initiated a campaign which made them active, dissenting subjects in public discourse about disease and disability. Its source was a core of Warm Springs patients who wanted more than a healing refuge. They were well aware of the need to construct a new image of the disabled, and saw the resort's high public profile as a potent weapon in a cultural war to remake popular images of the disabled, whether as pathetic charitable objects or as horrific movie villains. Drawing on their own, disheartening experiences, this group of activists boldly critiqued the medical care offered most disabled patients as well as the training and attitudes of doctors, nurses and physical therapists. Protesting the narrow, medicalized definition of rehabilitation, they provocatively posed the need to «rehabilitate» prejudiced, able-bodied employers and health professionals. And most of all, they consciously designed the polio center at Warm Springs to function not as an inward-looking refuge but as an exemplar of the way polio survivors and other disabled people should be allowed to live, work and love. This story begins and ends in the 1930s. It traces a rise and fall: the rise of an activist community at the rehabilitative center at Warm Springs; and its decline with the creation of the National Foundation for Infantile Paralysis (known popularly as the March of Dimes) in 1937.
\end{abstract}

KEY WORDS: Polio. Warm Springs. Rehabilitation.

\section{CRÓNICAS SOBRE LA POLIO: WARM SPRINGS Y LA POLÍTICA SOBRE LA MINUSVALÍA EN LOS AÑOS TREINTA}

\section{RESUMEN}

Durante los años veinte y treinta, un grupo de supervivientes de polio minusválidos entablaron una campaña que los convirtió en sujetos activos y discrepantes en el discurso público sobre enfermedad y minusvalía. El origen se sitúa en un grupo de pacientes de Warm Springs que querían algo más que un simple refugio curativo. Eran conscientes de la necesidad de crear una nueva imagen de los minusválidos y vieron en la importante imagen pública del centro una potente arma en una guerra cultural destinada a cambiar la imagen popular que se tenía de los minusválidos, ya fuera como patéticos objetos de obras benéficas o como horrendos personajes caracterizando siempre a los malos de la película. Basándose en sus propias y desalentadoras experiencias, este grupo de activistas criticaron abiertamente los cuidados médicos ofrecidos a la mayoría de pacientes minus- 
válidos así como la formación de los médicos, enfermeras y fisioterapeutas. Criticando la restringida y medicalizada definición de rehabilitación, plantearon de modo provocador la necesidad de «rehabilitar» a los empresarios sanos y con prejuicios así como a los profesionales de la salud. Y sobre todo, diseñaron a conciencia el centro para la polio de Warm Springs, para que funcionara, no como un refugio hermético e impenetrable, sino como un modelo que reflejara el derecho que tenían los supervivientes de la polio y otras personas minusválidas a vivir, trabajar y amar. Esta historia tiene su principio y su fin en los años treinta. Describe un ascenso y una caída: el ascenso de la comunidad activista en el centro de rehabilitación de Warm Springs y su caída, con la creación de la Fundación nacional para la parálisis infantil (conocida popularmente como March of Dimes) en 1937.

PALABRAS CLAVE: Polio. Warm Springs. Rehabilitación.

Historians of asylums and other medical institutions have long excoriated the discriminatory and infantilizing practices within, but they have often left the institutionalized inmates in shadows. But as the emerging field of disability studies has demonstrated, the mentally and physically disabled have their own, distinctive histories, in which such practices and values were contested. While we still know little about the history of most disabled men and women, a new autobiographical movement has begun to flesh out private and family lives full of struggle and inequity. Yet what about organized efforts to fight social assumptions about normality? During the 1920s and 1930s, disabled polio survivors initiated a campaign which made them active, dissenting subjects in public discourse about disease and disability. So effective was this campaign that others involved in polio philanthropy and funding, especially President Franklin Roosevelt's able-bodied advisors, considered it a political threat, and sought to displace the articulate adult polio survivor in the public mind with the nowfamiliar image of the polio poster child, vulnerable, silent and grateful. The development of the polio rehabilitation center at Warm Springs, Georgia, as a «community of the handicapped,» has frequently been noted by the many writers who have chronicled its history. ${ }^{1}$ But the social and political disability rights agenda that this community engendered has drawn surprisingly little attention.

Its source was a core of Warm Springs patients who wanted more than a healing refuge. They were well aware of the need to construct a new image of the disabled, and saw the resort's high public profile as a potent weapon in a cultural war to remake popular images of the disabled, whether as pathetic charitable objects or as horrific movie villains. ${ }^{2}$ This movement was intended

1 Gallagher, H.G. (1985), FDR's Splendid Deception, New York, Dodd, Mead, p. 55.

2 On popular stereotypes of physically disabled like Lon Chaney and other crippled villains in movies of the 1910s and 1920s, see NoRDEN, F. (1994), The Cinema of Isolation: A 
open the doors of rooms where shut-ins languished and hospital wards full of neglected, despairing children and adults. It would challenge the economics and politics of discrimination against the disabled, a difficult issue to raise during the Great Depression and in an era when the American eugenics movement continued to shape health and welfare policy. Drawing on their own, disheartening experiences, this group of activists boldly critiqued the medical care offered most disabled patients as well as the training and attitudes of doctors, nurses and physical therapists. Protesting the narrow, medicalized definition of rehabilitation, they provocatively posed the need to «rehabilitate» prejudiced, able-bodied employers and health professionals. And most of all, they consciously designed the polio center at Warm Springs to function not as an inward-looking refuge but as an exemplar of the way polio survivors and other disabled people should be allowed to live, work and love.

This story begins and ends in the 1930s. It traces a rise and fall: the rise of an activist community at the rehabilitative center at Warm Springs; and its decline with the creation of the National Foundation for Infantile Paralysis (known popularly as the March of Dimes) in 1937. Disabled adults at Warm Springs used their connection with Warm Springs founder Franklin Roosevelt to articulate forcefully their own notion of health policy and disability rights. As part of their own version of disease fund-raising, this group of polio activists tried to redefine the political as well as the medical parameters of «rehabilitation». But over time, and as part of a deliberate strategy, Roosevelt retreated from this community to become the center's figurehead, holding oversized checks and making ceremonial speeches to thank the American people for their charitable donations. The separation from Warm Springs activism was spurred by Roosevelt's advisors — mostly able-bodied lawyers and businessmen — who saw grave political dangers in linking President Roosevelt and polio philanthropy with the adult disabled. Although in private Warm Springs remained Roosevelt's personal refuge from the able-bodied world, in his public politics he presented himself as cured - a former cripple, who had overcome paralysis.

Roosevelt's advisors moved polio fund-raising away from any agenda related to the social integration of the disabled into a safely sentimentalized

\footnotetext{
History of Physical Disability in the Movies, New Brunswick, Rutgers University Press. On the model of another disabled lobbyist and fundraiser see NiELSEN, K.E. (2004), The Radical Lives of Helen Keller, New York, New York University Press, pp. 47-48; and NiELSEN, K.E. (2001), Helen Keller and the Politics of Civic Fitness. In Longmore, P.K. and Umansky, L. (eds.), The New Disability History: American Perspectives, Albany, New York University Press, pp. 268-290.
} 
search for normality. This revised vision of polio campaigning ignored the reality of permanent disability by promising a fearful public that polio survivors could conquer any visible signs of crippling, and «overcome» paralysis to achieve again a «normal» body. ${ }^{3}$ The March of Dimes poster child campaign was part of an explicit strategy to depoliticize polio - a perspective that sheds a new light on the familiar story of Roosevelt's efforts to present himself as a man who had conquered pain and disability, not one who continued to rely on braces, a wheelchair, the arms of his sons, and the self-censorship of reporters and photographers. This story of politics and disease makes us aware not just of the silence of Roosevelt as a disabled man, but of the silencing of other disabled polio survivors, struggling to battle prejudice and physical barriers.

\section{THE CREATION OF WARM SPRINGS AS A DISABLED COMMUNITY, 1924-1931}

Franklin Delano Roosevelt contracted polio in 1921, at the age of thirtynine. Like many other paralyzed polio survivors, he had desperately tried diverse therapeutic regimens, both orthodox and alternative. He swam in the pool at his Hyde Park estate, baked under an ultra-violet ray sun-lamp, and consulted two osteopaths (visits he did not mention to his regular doctors, George Draper and Robert W. Lovett, both eminent polio specialists). ${ }^{4}$ But none of these therapies strengthened his legs or enabled him to walk. Would he be unable to reenter political life, forced like some wealthy disabled men and women to retire from public life and (as his mother urged) take up art collecting? ${ }^{5}$

3 See Wilson, D.J. (2005), Living with Polio: The Epidemic and its Survivors, Chicago, University of Chicago Press.

4 He also tried massage, electric current, horseback riding, electric tricycle, warm and cold water, and parallel bars; see GALLAGHER (1985), p. 24; GUNTHER, J. (1950), Roosevelt in Retrospect: A Profile in History, New York, Harper and Brothers, pp. 35, 42-43, 234; Gould, T. (1995), A Summer Plague: Polio and its Survivors, New Haven-London, Yale University Press, p. 42. He told George Draper, "I have seen the methods of practically all the other doctors in the country - the Lovett method, Goldthwaite method, Hibbs method, St. Louis method, Chicago method, etc. etc.;» Roosevelt to Draper (1935) quoted in LIPPMAN, T.Jr. (1977), The Squire of Warm Springs: F.D.R. in Georgia 1924-1945, Chicago, Playboy Press, p. 40. He also worked with a nerve specialist who made his polio patients use a "walking board»; LIPPMAN (1977), p. 48; DAVIS, K.S. (1974), Invincible Summer: An Intimate Portrait of The Roosevelts Based on the Recollections of Marion Dickerman, New York, Atheneum, p. 62.

5 GUNTHER (1950), pp. 222-224; Gould (1995), pp. 29-40. On «my quiet ideas for his future existence», see My Boy Franklin as told by Mrs. James Roosevelt to Isabel 
Then one day Roosevelt received a letter from a young man whose legs, paralyzed like his, had been healed after swimming at a run-down summer resort in rural Georgia. ${ }^{6}$ At Warm Springs Roosevelt enthusiastically tried out the pools, marveling at his body's buoyancy in the hot, mineral-rich water. ${ }^{7} \mathrm{He}$ began staying there regularly, mixing with the able-bodied resort guests and the small numbers of polio survivors who began arriving after the publicizing of Roosevelt's efforts in a syndicated article in the Atlanta Journal. Unhappy with this disabled onslaught, the able-bodied guests tried to recapture society's socially acceptable segregation by making the polio patients eat in the hotel basement. ${ }^{8}$ Roosevelt organized a separate pool and a separate dining facility in the hotel basement with wheelchair access. Roosevelt's son James recalled his father's «cold anger over this intolerant attitude,» and believed that it «made him even more determined to create an esprit at Warm Springs which would brook no condescension, no mawkish pity.» ${ }^{9}$ Able to afford the best medical care and largely protected from the worst of such prejudice, Roosevelt was shocked to hear about his new friends' "shut-in» experiences. ${ }^{10}$

Leighton and Gabrielle Forbush, 1933, New York, Long and Smith, p. 101. For insightful examples of Roosevelt as a model to the disabled in this period, see WILSON, D.J. (1998), A Crippling Fear: Experiencing Polio in the Era of FDR, Bulletin of the History of Medicine, 72, pp. 464-49; and FAIRCHILD, A.L. (2001), The Polio Narratives: Dialogues with FDR, Bulletin of the History of Medicine, 75, pp. 488-534.

6 LipPMAN (1977), pp. 32-34. This visit was carefully coordinated by friends of Roosevelt who knew of his desperate search for a cure. The run-down resort was run by a Warm Springs Company, headed by Columbus newspaper editor Thomas Loyless, who had leased the hotel around 1919, and contacted Boston banker George Foster Peabody to try to revive it and gain a reputation in the north. In 1923 Peabody, after hearing Loyless mention Louis W. Joseph, urged him to get Joseph to write to Roosevelt. Louis W. Joseph, nephew of a family who spent summers near Warm Springs, was a New York civil engineer; WALKER, T. (1953), Roosevelt and the Warm Springs Story, New York, A.A. Wyn, pp. 14-16; SteVEns, R. (1947), Hi Ya Neighbor: Intimate Glimpes of Franklin D. Roosevelt at Warm Springs, Georgea, 1924-1945, New York, Tupper and Love; WorSLEY, E.B. (Summer 1949), Warm Springs, Georgia Review, 3, pp. 233-244; LIPPMAN (1977), pp. 32-34; GUNTHER (1950), pp. 232-233.

7 LiPPMAN (1977), pp. 32-34. GUNTHER (1950), pp, 232-233.

8 LipPMAN (1977), pp. 47; GoUld (1995), p. 46.

9 Roosevelt, J., Shalett, S. (1959), Affectionately, F.D.R.: A Son's Story of a Lonely Man, New York, Harcourt, Brace, pp. 189, 191; see Gould, J. (1960), A Good Fight: The Story of F.D.R. 's Conquest of Polio, New York, Dodd, Mead and Company, pp. 132-133.

10 See Gallagher (1985), p. 29. On Roosevelt saying «by personal good fortune I was able to get the best kind of care» (part of a campaign speech in Rochester during 1928 campaign for governor); see Gould (1960), p. 191; HouCK, D.W. and KIEWE, A. (2003), FDR's 
In 1926, imagining he could transform it into a combination of health resort and country club, Roosevelt decided to buy Warm Springs. ${ }^{11}$ A year later, pressured by his advisors, who could see that few able-bodied prospective guests would be interested in vacationing with disabled polio survivors, Roosevelt agreed to transform Warm Springs solely into a rehabilitation center, and formally incorporated it as the Georgia Warm Springs Foundation, a nonprofit company eligible for tax-free gifts and grants. ${ }^{12}$ With donations from two industrialists with daughters at Warm Springs and other wealthy associates, Roosevelt was able to begin an ambitious renovation program, paving local roads, redesigning the grounds, and upgrading the cottages with electricity and running water. By 1932 there were three pools: a public pool, an open treatment pool, and a new indoor pool enclosed in glass, the result of a $\$ 25,000$ gift from Henry Ford's son Edsel. ${ }^{13}$

The story of Warm Springs has most often been told as part of Roosevelt's political career. His subsequent political successes helped give the center distinctive prominence. Although in later retellings of Warm Springs history Roosevelt portrayed himself as a reluctant newspaper informant, in fact he had welcomed Atlanta Journal reporter Cleburne Gregory as part of a campaign both to publicize the resort and to remake himself in the image of a healed man who could return to public life. ${ }^{14}$

Body Politics: The Rethoric of Disability, College Station, Texas, pp. 47-48. For patient experiences of polio care in the 1930s, 1940s and 1950s see BLACK, K. (1996), In the Shadow of Polio: A Personal and Social History, Reading, Mass., Addison-Wesley; Daniel, T.M., RoBBINS, F.C. (eds.) (1997), Polio, Rochester, University of Rochester Press; SASS, E.J., GotTFRIED, G., Sorem, A. (eds.) (1996), Polio's Legacy: An Oral History, Lanham, MD, University Press of America; and Gilden Seavey, N., Smith, J.S., Wagner, P. (1998), A Paralyzing Fear: The Triumph over Polio in America, New York, TV Books.

11 LIPPMAN (1977), pp. 31-43. For Roosevelt the venture was intended to be profitable as well as therapeutic. During 1927 he entertained «wealthy prospects» to try to convince them to invest in the resort, and he bought an additional 1,750 acres to try additional experiments in farming timber and cattle; Rollins, A.B.Jr. (1962), Roosevelt and Howe, New York, Alfred A. Knopf, p. 204. On the fight between Eleanor and Franklin over his decision to buy the property and surrounding lands for $\$ 195,000$, and then to invest two-thirds of his trust into its upkeep, see WIESEN COOK, B. (1992), Eleanor Roosevelt: Volume One, 1884-1933, New York, Viking, p. 335. His friends feared the resort would go the way of earlier interests in lobsters, oil wells, and other ventures.

12 The title «Georgia» was probably added because there were well-known other «warm springs» linked to health resorts.

13 Lippman (1977), p. 49; Gallagher (1985), pp. 49-50. They were James Whitehead and Henry Pope.

14 Gould (1960). 
Most of the first visitors to Warm Springs were wealthy adults seeking, like Roosevelt, another possibility for healing, and trusting in the power of the distinctive environment as well as the warm waters. In Europe and America, thermal spas had long combined health maintenance (wellness), convalescent care (rehabilitation) and chronic care (pain management). ${ }^{15}$ Their comfort and beauty were in stark contrast to state-funded sanatoria or homes for «the ruptured and crippled,» institutions that were, as polio historian Hugh Gallagher has noted, inadequate, ineffectual and grim. ${ }^{16}$

Although he was well aware of the dangers of medicalizing disability, neither did Roosevelt want Warm Springs to become a home for crackpot enthusiasts, ignorant of scientific rigor and the best medical care. He appealed to respected physicians to act as consultants and staff. ${ }^{17} \mathrm{He}$ was able to interest orthopedic surgeon Leroy W. Hubbard, just retired from the New York State Board of Health, to become Warm Springs surgeon-in-chief. Hubbard invited his former assistant Helena Mahoney to work as the resort's head physical therapist. ${ }^{18}$ By 1929, Hubbard's board of consultants included Roosevelt's own polio specialist George Draper, Boston orthopedists Arthur Legg and Frank Ober, and Baltimore surgeon George E. Bennett, as well as a staff of twelve physiotherapists. ${ }^{19}$ In 1931 Hubbard was replaced by orthopedic surgeon Michael Hoke who had worked with disabled children at the Scottish Rite Hospital in Atlanta, and later Charles Edwin Irwin became the head surgeon. ${ }^{20}$ When Mahoney retired she was replaced by Alice Lou Plastridge,

15 See Rothman, S.M. (1994), Living in the Shadow of Death: Tuberculosis and the Social Experience of Illness in American History, New York, Basic; On the continuing use of open-air institutions for tuberculosis see BATES, B. (1992), Bargaining for Life: A Social History of Tuberculosis, 1876-1936, Philadelphia, University of Pennsylvania, pp. 173-196.

16 Gallagher (1985), pp. 28-33.

17 In an unusual gesture, he traveled to a meeting in April 1926 of the American Orthopedic Association in nearby Atlanta to lobby for its members' approval of Warm Springs as a rehabilitation center; GouLD (1960), pp. 166-167. In January 1927, after a report by Hubbard, the AOA agreed to approve the establishment of a «permanent hydrotherapeutic center» at Warm Springs; GALLAGHER (1985), pp. 46-47.

18 Gould (1960), pp. 153-160. On the board of medical consultants set up in 1928 see ReEves Solenberger, E. (October 1930), Warm Water Healing, Hygeia, 8, p. 914.

19 HubBard, L.W., Annual Report of the Surgeon-Chief, George Warm Springs Foundation, Incorporated (1929), disabilitymuseum.org/lib/docs/2166.htm (03/04/2009). The reports detailed the numbers of patients, categorized by age and sex, by affected limb, by the length of time they had been paralyzed. In 1929, of the 215 patients he noted, thirty-seven were disabled by a disease other than polio.

20 «Dr. Michael Hoke, Noted Surgeon, 70», New York Times (September 25 1944). 
who had been trained in Boston and had come to Warm Springs as the personal therapist of polio patient Margaret Pope, daughter of a wealthy Chicago hosiery manufacturer. ${ }^{21}$

The bulk of Roosevelt's personal efforts, however, went to reinforcing the developing convivial community whose members shared his view that «it must never become a hospital.» ${ }^{22} \mathrm{He}$ hired a corps of female physical therapy graduates from Nashville's Peabody College for Women, a group once photographed in a publicity stunt lined up by the pool like «bathing beauties.» ${ }^{23}$ Known as «physios,» they were, a patient remarked in 1932, «a squad of lean, brown, alert young women on the job at the pools each day in bathing suits, back at the Inn for luncheon in sports clothes that match their tan ... giving out the charm of their abundant vitality when the day's work is done.. ${ }^{24}$ Good-looking young men were also made part of the staff. To assist patients who needed to be lifted and to have their wheelchairs moved, Roosevelt hired «sun-browned» and «stalwart» students from the local high school who became known as «push boys.»» 25

With the help of an architect friend Roosevelt renovated the central building, the old Meriwether Inn, and then tore it down and rebuilt it as Georgia Hall. But he retained the early-twentieth century resort feeling of "southern antebellum elegance, old money, good taste, good family, careless luxury.» ${ }^{26}$ Meals were festive, tables set with good china and linen napkins, and food served by black waiters in white dinner jackets. ${ }^{27}$ There were bridge tournaments, cocktail parties and picnics. At formal dinner parties, the tables were marked by place cards, and the hostess signaled «from the head of the table when you were supposed to turn from the partner on your left and make conversation to the partner on your right. $\rangle^{28}$

Warm Springs rapidly became a showcase for polio rehabilitation, open to

21 LipPMAn (1977), p. 48; Gould (1960), p. 167. On Plastridge «trained under Goldthwait, Lovett and Legg of Boston and the leading orthopedic surgeons in Chicago;» see Georgia Warm Springs Foundation, (May 6 1933), JAMA, 100, p. 1453.

22 Quoted in LiPPMAN (1977), p. 200. «It's got to be a whole lot more than a hospital,» Roosevelt supposedly told his friend and legal partner Basil O'Connor, «nobody should go all this way to be shut up inside a big white building;» WALKER (1953), p. 184.

23 WALKER (1953), pp. 154-155; GOULD (1995), p. 50.

24 Donnelly, R.L. (June 1932), Playing Polio At Warm Springs, Polio Chronicle.

25 Donnelly (June 1932).

26 Plagemann, B. (1990), An American Past: An Early Autobiography, New York, William Morrow, p. 168.

27 Ibidem.

28 Plagemann (1990), p. 172. 
relatives and friends, reporters, Roosevelt's political allies, and visiting physical therapists, nurses and doctors. Patients' families could stay in rented cottages or rooms in local boarding houses. For children there were pony carts and a "colored man who knows all there is to be known about horses,» while able-bodied adults could enjoy a small golf course, tennis courts, a public pool «filled with the same warm spring water,» and automobiles for hire. Warm Springs became a cultural icon featured on postcards and even china. ${ }^{29}$

Warm Springs gradually became a refuge from discrimination with the promise of rehabilitation in joyful surroundings. But from the beginning it was a whites-only refuge. Although Roosevelt's New Deal administration with its liberal racial pluralism later alienated many Southern white Democrats, at this Georgia resort Roosevelt was careful not to challenge what he termed «local customs,» and kept the Warm Springs patients, administrators and medical staff white. ${ }^{30}$ Of course, typical of other wealthy Southern institutions, African Americans were employed as maids, waiters, body servants, gardeners and janitors. Few of these men and women appear in the Warm Springs published sources. In 1932 one patient did briefly describe «Sarah,» a «most diverting person,» who had been born nearby, and had worked at the hotel «when there was jes' bo'ders.» «Pouring olive oil on skins that have not known the sun, adjusting bathing suits, fetching towels, wheeling chairs ... tall, gaunt, black, old, with her sun hat and bony hands, Sarah is everybody's friend,» according to the writer, turning her into a stereotypical Mammy who always encouraged the patients: "'Cose yo' can learn to swim. Come to yo' all at once. Fust thing yo knows yo'll be going right across the pool by yo'self. Yas, $m a{ }^{\prime} a m$. ' $>{ }^{31}$

Setting up the Warm Springs Foundation may have been a convenient legal stratagem for Roosevelt and his advisors to make sure he was linked to a respectable-sounding non-profit organization rather than a money-making private resort. But for the adults at Warm Springs, the foundation was much more. It was also a disabled civil rights organization with a bold national agenda. Here «education» meant both introducing the latest methods to doctors and other health professionals who had neglected and poorly treated their paralyzed patients, and also «training» employers to see the physically disabled as worthy employees.

29 DONNELLY (June 1932); LiPPMAN (1977), pp. 201-202.

30 Commentators have argued that the resort's segregation was a significant reason for Eleanor Roosevelt's dislike of Warm Springs; Roosevelt, SHALETT (1959), p. 186.

31 DonNELLY (June 1932). 


\section{THE CRUSADE BEGINS}

The 1931 polio epidemic, which occurred while Roosevelt was governor of New York, was the nation's worst since 1916, and spurred the transformation of Warm Springs from social refuge to political base. ${ }^{32}$ In June 1931 the adult patients and staff at Warm Springs organized a National Patients Committee, its slogan «Every Patient, a Polio Crusader.» ${ }^{33}$ Aware that polio, unlike other diseases, had no national public presence or specific voluntary association to promote it, the first job of the National Patients Committee was to raise public awareness. "If you are not polio conscious, you should be polio conscious - just as you are cancer conscious and tuberculosis conscious,» organizer William Woodin argued, urging those who had contributed time and money toward «possible eradication and alleviation of THESE ills» to be willing to contribute equally to «the cause of polio.»" 34

The tone of this new polio crusade was deliberately disarming. Designed to «disseminate information» and to provide «an outlet» for enthusiastic former patients, the National Patients Committee (made up of «a group of active patients») suggested those who had received treatment at Warm Springs and returned home should work for the «benefit» of those «recently afflicted» by polio. To challenge the neglect of «shut-ins,» disabled activists were urged to raise funds so that new polio cases could receive expert medical supervision «at some recognized institution.» They could also by their words and bodies offer an alternative to the therapeutic nihilism and despair confronting the newly disabled, visiting their homes and assuring them and their doctors that «the world for them has not come to an end.» The disabled visitor would also speak of hope for at least partial rehabilitation and the availability of medical advice from the Warm Springs medical staff. During epidemics such activists might also offer suggestions to local health authorities, speaking as a different kind of polio expert. ${ }^{35}$

A final organizational meeting for the National Patients Committee held in July 1931 was attended by around a hundred patients and another hundred

32 Anon. (September 1931), The Crusade Against Polio, Polio Chronicle; Anon. (April 1932), Notes of the National Patients' Committee, Polio Chronicle; Paul, J.R. (1971), A History of Poliomyelitis, New Haven, Yale University Press, pp. 200-211.

33 LiPPMAN (1977), pp. 201-202; Gould (1995), pp. 55-56.

34 Woodin, W.H. (July 1931), Are You Polio Conscious?, Polio Chronicle.

35 Botts, F. (July 1931), Announcing the New National Patients Committee, Polio Chronicle. 
friends and family members. Within a few months the first issue of the Polio Chronicle appeared, an eight - page newsletter designed to be read by those at Warm Springs and the «polio conscious» around the country. The Committee established a series of subcommittees: Finance; Publicity (including «Education of the Public on Poliomyelitis»); Insurance for Polios; Entertainment; Motor Licenses for Handicapped People; and Architectural Suggestions and Mechanical Hints. ${ }^{36}$ By 1932 another subcommittee was preparing a directory of hotels for the disabled, and the architectural committee was investigating hand-control devices for automobiles. The finance committee already had $\$ 7,000^{37}$. After joining the Polio Crusade, members received a membership certificate, a pin and a subscription to the Polio Chronicle which, by 1933, claimed a readership of 2,500. Using terms more typical of a college than a hospital or a spa, the Chronicle urged all «Warm Springs undergraduates and alumni» to join the crusade, for "your gift will give some polio new hope, new life, and new usefulness to society.. ${ }^{38}$

The word «crusade» had an inspiring, evangelical ring and sounded a familiar tone for charities and single-disease philanthropies like the National Tuberculosis Association. ${ }^{39}$ Although the Warm Springs Polio Crusade was similarly designed to raise money for the «victims» of a single disease, its tone and intent was quite distinct. Designed and run by disabled adults, the crusade raised serious issues like employment, medical care and social discrimination; and instead of being portrayed as grateful objects of charity, the patients were in control of the crusade.

While a slogan like «Every Patient, a Polio Crusader» was inspiring, the campaign sent contradictory messages, just as Roosevelt did through his own public relationship to polio and to his disability. ${ }^{40}$ Polio conscious did not

36 Donovan L.K. (August 1931), National Patients' Committee of the George Warm Springs Foundation, Polio Chronicle.

37 Anon. (April 1932), Notes of the National Patients' Committee, Polio Chronicle.

38 Anon. (September 1931), The Crusade Against Polio, Polio Chronicle; SMith, A. (June 1932), Please Join the Polio Crusaders, NOW!, Polio Chronicle; Anon. (April 1932); Anon. (June 1933), Condemned?, Polio Chronicle; Anon. (July 1933), In the Spirit of 1933: The Georgia Warm Springs Foundation Looks Forward, Polio Chronicle.

39 See Tomes, N. (1998), The Gospel of Germs: Men, Women, and the Microbe in American Life, Cambridge, Harvard University Press; FeldBERG, G.D. (1995), Disease and Class: Tuberculosis and the Shaping of Modern North American Society, New Brunswick, Rutgers University Press.

40 On this point see Gallagher (1985), and DufFy, J. (1987), Franklin Rossevelt: Ambiguous Symbol for Disabled Americans, Midwest Quaterly, 29, pp. 113-135. 
mean disability conscious, and Roosevelt's example was inspiring yet ambiguous. As governor of New York he had urged the legislature to give disabled adults opportunities for «useful citizenship,» and in 1932 as president-elect he had announced that «we need to make America 'polio conscious' to the end that the inexcusable case of positive neglect will be entirely eliminated.» ${ }^{41}$ But as his shift from speaking on crutches at the 1924 Democratic National Convention to using only a cane and the assistance of his sons at the 1928 convention emblematized, as he sought political power Roosevelt moved to a strategy to convince the public that he had conquered his disability and could walk without crutches, the «universal symbol» of the cripple. ${ }^{42}$

With a similar pragmatism about normality and subterfuge, physical therapist Alice Lou Plastridge in an article on «Corrective Walking» offered ways that polio survivors could avoid «habit limps» that might persist after muscles had been strengthened, in order to make "walking inconspicuous ... without needless body, leg or arm motions which would attract attention to the disability. $\rangle^{43}$ Accessibility was a constant theme among Warm Springs activists. The «paral, like anyone else,» one writer in the Polio Chronicle reflected in 1934, «should feel that all people and places, thought and actions, arts and science, are open to him. Physical handicap should raise no barrier against him.» ${ }^{44}$ Yet they also knew that Roosevelt's staff built ramps so he could visit public buildings and then tore them down after he left.

Roosevelt was frequently represented as having put disease and disability «behind» him. The National Patients Committee similarly presented «handicap» as a psychological rather than a physical barrier, and noted without criticism the occupations many former patients pursued which allowed them to work out of sight in a socially acceptable way. One writer praised Roosevelt's influence on the Polio Crusade, for he had «laid the cornerstone of a great movement, cemented in COURAGE, ENDEAVOR, PATIENCE AND PERSEVERANCE. $\rangle^{45}$ This was the conservative worldview in which normality was to be gained through will power, and frustration and despair were understood as rooted not in material but in emotional causes. When visitors talk of

41 Gallagher (1985), p. 78; Gould (1995), p. 54; DufFy (1987).

42 Gallagher (1985), p. 68, «as a man who had not merely struggled, but had triumphed over his crippling disease». All this was part of Roosevelt's fight to «lick polio», which according to GOULD (1995), p. 58 was made up of a "combination of will power and guile that was to make him a great president he made it cease to matter»».

43 Plastridgçe, A.L. (October 1932), Corrective Walking, Polio Chronicle.

44 Anon. (February 1934), Accessibility, Polio Chronicle.

45 Donovan (August 1931). 
courage, argued one Chronicle editorial, it was «just so much tripe,» for working to be able to regain economic independence was «the natural thing» and «requires no great amount of courage.» What was appalling were the number of polio survivors who «are content to say, «I'm a cripple,» find a soft cushion, and just sit ... playing bridge and learning to tat.» «The polios who do nothing are those who will never be more than parasites on wheels. $\rangle^{46}$

\section{A POLIO'S PARADISE?}

Warm Springs patients saw themselves as pioneers, creating history «in the making. ${ }^{47}$ When the main building had to be renovated, the patients rejected the idea of dormitory housing, and urged that the surrounding cottages continue to be used as «living quarters,» but improved with plaster walls, electric outlets, refinished floors, medicine cabinets, wall hand-rails, and «more attractive furnishings. ${ }^{48}$ «Representative patients» also assessed the plans for designing the main building and sought to «make Georgia Hall truly 'A Polio's Paradise.'» Along with ramps and level floors, the main door leading into Georgia Hall was designed with «a photo-electric cell» so that «when the light beam is broken, the door automatically swings open.» ${ }^{49}$

Physical accessibility was a major part of what made Warm Springs a «Polio's Paradise.» Buildings had no steps or thresholds, and, one patient noted cheerfully, «everything is on the level ... cottages and pools are a stairless Eden. ${ }^{50}$ Warm Springs patients compared the freedom of movement available in the center to the harsh, restrictive lives familiar to many disabled people. ${ }^{51}$ Here they were able to crawl, roll and admit physical and emotional weakness, "sealed off against a lovely mountain slope, far from the world where everybody walked. $\rangle^{52}$ Often hard it was to leave. Turnley Walker recalled how safe he felt as «a badly crippled man» at Warm Springs where «the outside world had moved far away.» When it was time for him to leave, his wife was excited and happy but Walker was terrified to «continue the journey

46 Editorial (April 1933), Polio Courage, The Polio Chronicle.

47 Donnelly (June 1932); and see BotTS, F. (c. 1930), Where Infantile Paralysis Gets Its «Walking Papers», www.disabilitymuseum.org/lib/docs/2124.htm (03/04/2009).

48 Anon. (July 1933).

49 Anon. (July 1933); Anon. (February 1934).

50 DONNELLY (June 1932).

51 See BLACK, In the Shadow of Polio, pp. 171-185.

52 WaLker, T. (1951), Journey Together, New York, David McKay Company, p. 30. 
back into the outside world where a cripple was a cripple and a 'problem' to everyone around him. $\rangle^{53}$ Later Walker, whose rehabilitative experiences at a New York hospital, Rise Up and Walk, became a Book of the Month Club selection, attacked the fantasy of this refuge. He now shared the «glum» assessment of another former patient he had met who told him that «outside, every place is full of other people, normal people, and they set the pace ... and nothing's built on the level ... When you fall down, they don't know what to do. Outside, people hate to see you coming. $\rangle^{54}$

Throughout the Polio Chronicle were articles and advertisements offering technologies to allow polio survivors access to what their able-bodied peers could reach, and to make the world outside Warms Springs more accessible. There were helpful hints on how to enter the front and back seats of a car, and a glowing description of the new Miracle Drive car whose automatic transmission was an innovation in the 1930s. Families could also buy an electric stair chair and diverse kinds of wheelchairs. ${ }^{55}$

Beyond these individualist techniques, the National Patients Committee began to promote what it called the "Lovewell Plan,» a campaign to make public buildings more accessible to the disabled. Roosevelt's New Deal Administration had begun to build America's infrastructure, but most of the new public buildings, designed in a popular neo-classical style, were inaccessible to the disabled. The Committee proposed a National Roll of Honor to recognize those public buildings which met a minimum requirement: handrails on both sides of one or more public entrances where steps occurred, and a ramp entrance somewhere around the building. ${ }^{56}$ The elements of this campaign were first articulated in a series of articles by Warm Springs patient Reinette Lovewell Donnelly, a journalist already published in McCall's and other family magazines.

«I used to dream that when I grew up I'd make a lot of money - the perennial dream of childhood - and put stout hand railings on all the ramps in the world,» Donnelly reflected in the Polio Chronicle. ${ }^{57}$ But instead she had

53 WALKER (1951), pp. 88, 79. In 1950 his book on his experiences in the New York Hospital Rise Up and Walk was chosen by the Book of the Month Club.

54 WALKER (1951), pp. 32-33.

55 Mechanical Hunts (September 1931), The Polio Chronicle; Going Up? (December 1932), The Polio Chronicle; Do You Drive, Polio (January 1933), The Polio Chronicle.

56 Editor's Note, DonNelly, R.L. (February 1933), Watch Your Steps, The Polio Chronicle.

57 Ibidem. 
begun understand accessibility as a civil right, one to be broadly recognized by architects and other designers of public spaces. There was an elevator that could be taken to the top of the Empire State building, for example, but to get to the observation terrace there were «three modernisticly lovely steps, walled in with shining metal planes impossible to grip for support.» ${ }^{58}$ «Churches, libraries, colleges, post offices, courthouses, city and state federal buildings, railway stations - not all, but many, have stairways which are either impossible or very difficult for people of faulty locomotion.» ${ }^{59}$ Equipping «stairways with railings and the provision of ramps all over the country» should be considered by the American public «as something supremely courteous» and «there

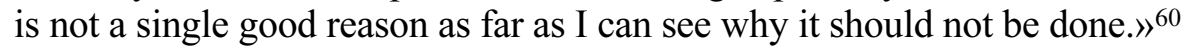

Here was the sense of Warm Springs not as an inward-looking refuge but as an exemplar of a fair world where the disabled could move around just like the able-bodied. Expanding public access was partly a question of social justice and partly a question of constructing a new kind of body politics. To make what seemed like a special interest demand into a public right, these Polio Crusaders set out to develop a public persona that moved away from pathetic supplication toward feisty, hedonist demands for an emotional and independent life.

\section{THE CRUSADE RADICALIZES}

The Warm Springs community was characterized by a satirical sense of humor that shocked outsiders. Patients frequently designed theatrical productions — such as the «Poliopolitan Opera Company» - that mocked «ordinary» life and showcased their own artistic talents. ${ }^{61}$ The jokes were sometimes sharp. Roosevelt used to tell a story about a boy at Warm Springs in a wheelchair who snapped at some «able-bodies» staring at him, «Stick around! They're going to feed us after awhile. $\rangle^{62}$ A sardonic tone appeared in the car-

58 Ibidem.

59 Ibidem.

60 Ibidem.

61 On shows performed in 1936 and 1937 see GouLD (1995), p. 82; on the musical «A Sailor's Sweetheart: The S.S. 'Paral-Brace Lines'» performed for Roosevelt in 1943 see MASON, M.G. (1999), Life Prints: A Memoir of Healing and Discovery, New York, Feminist Press, p. 9.

62 Roosevelt, Shalett (1959), p. 191; repeated in Roosevelt, J., LibBy, B. (1976), My Parents: A Differing View, Chicago, Playboy Press, p. 88. Patients also enjoyed the ways that push boys mocked the sentimentality associated with visiting the disabled; one told visitors that a dip in the fountain had cured him, and threw his friend sitting in a wheelchair into 
toons in the Polio Chronicle. William Bolte Gibson, later a cartoonist for the Camden Courier-Post, drew a series featuring «the Old Paral.» In one cartoon a man sits in a wheelchair with a crying baby while his wife sleeps soundly in a nearby bed. The caption reads, "When I married I said, 'Oh, well, I won't have to walk the baby' - But now look at me!» ${ }^{63}$ Much of this humor highlighted hedonist pleasures like drinking and flirting. In George Salmon, Jr.'s «Polio Pete» series, a man in a suit has added to one of his crutches a clamp for «a beer mug» and «a telescoping rack for pretzels.» ${ }^{64}$ In another drawing a man sits next to a woman resting her head on his shoulder with the caption «Polio Pete Suggests Double Wheel Chairs to Accompany the Shrubbery at Georgia Hall. ${ }^{65}$ A pretty young woman with visible braces and crutches appears alongside a portly man in a morning coat in an illustration that accompanies the limerick: «There was a paral from the Bronx/ Who wasn't so good on harmonx/ But she married a guy/ Whose income was high/ Now her braces are studded with onx.» ${ }^{66}$

Similarly, the photographs that the National Patients Committee chose to promote itself and its work portrayed adults using clearly visible wheelchairs, braces and crutches. A series featuring the Committee's executive showed men and women looking competent and serious. Another article described a young reporter's achievements accompanied by a photograph of him standing with crutches, his hands comfortably and assertively on his hips. ${ }^{67}$ Men and women of various ages with crutches and in wheelchairs were the deliberate subjects of a photographic collage with the caption «Polio does not come to childhood alone. Men and women in the[ir] fifties are victims of the disease and often much more severely disabled than young folk.» ${ }^{68}$ Capturing some of the joy experienced at Warm Springs was a photograph of «Just a Couple

the fountain, «in front of the shocked visitors, the 'crippled' lad floundered about for a few moments, then leaped out and ran across the lawn hollering, 'I'm cured! I'm cured!» or would sit in wheelchairs, pretending they were too poor for the «miracle treatments» and beg for money «from unsuspecting and sympathetic tourists;» ROOSEVELT, SHALETT (1959), pp. 191192; repeated in RoOSEVELT, LiBBY (1976), p. 88.

63 Gibson, B. (September 1931), The Old Paral Says, Polio Chronicle.

64 Salmon, G. Jr. (August 1933), Polio Pete, Polio Chronicle.

65 SAlmon, G. Jr. (July 1933), Polio Pete Suggests Double Wheel Chair to Accompany the Shrubbery at Georgia Hall, Polio Chronicle.

66 Anon. (August 1932), A Paral from the Bronx, Polio Chronicle.

67 Anon. (September 1932), Louis Weinberg, [illustration] Comebacks from Polio, Polio Chronicle.

68 Anon. (June 1932), Polio does not come to childhood alone, Polio Chronicle. 
of Gals 'Breakin' Down,» a snapshot of an outdoor celebration of Roosevelt's birthday with young women in wheelchairs grinning at each other as they played their banjos. ${ }^{69}$ In a series of photographs entitled «Rehabilitation Requires,» two smiling couples were shown seated in a long rocking chair under the title «Rehabilitation requires SOCAL CONTACT»; and under «Rehabilitation requires WORK,» a serious man writes at a desk with a crutch propped up next to him and an additional caption: «A polio is like anyone else. Happiness lies in the good job well done. $\rangle^{70}$ These images were worlds away from typical fund-raising techniques, such as the suggestion by one of Roosevelt's advisors in the late 1920s that he raise money for Warm Springs by designing some «before and after» patient photographs, like «one photograph showing them doing a hundred yard dash or shoveling coal or something ... together with the statement that, when they arrived, it required two stretchers and an ambulance to get them down to the pool.»>11

The National Patient Committee's first president was John Ruhrah, a wellknown pediatrician who had been traveling in Europe when he was paralyzed by polio and arrived in Warm Springs in April 1931. By the fall he «astonished» his colleagues in Baltimore by returning to his medical practice. Like other Warm Springs alumni he frequently returned to the resort, combining vacation with rehabilitation. ${ }^{72}$ In a series of articles published first in the $P o$ lio Chronicle and then in the Journal of the Medical Association of Georgia and the Journal of the American Medical Association, Ruhrah pointedly compared paralyzed patients «at home» who were «watched over, pitied and spoiled by being waited upon while only too often neglected in other ways» to those at Warm Springs. ${ }^{73}$ There, a «spirit of independence» prevailed so that

69 Anon. (February 1934), Just a Couple of Gals 'Breakin' Down', Polio Chronicle.

70 Anon. (August 1933), Rehabilitation Requires, Polio Chronicle.

71 Lippman (1977), p. 41; Howe to Roosevelt, April 1 1927, quoted in Rollins (1962), pp. 203-204. Howe encouraged him to consider a chain of resorts from Lake Placid to Warm Springs.

72 Anon. (October 1932), A Change in Administration, The Polio Chronicle; Dr. John Ruhrah, Pediatrician, Dies, New York Times (March 11, 1935). Ruhrah had been president of the American Pediatric Society in 1924, professor of the diseases of children at the University of Maryland medical school, and in 1934 was elected president of the American Academy of Pediatrics. In Baltimore he continued his medical practice, radio lectures and writing.

73 See RuhraH, J. (1932), The Georgia Warm Springs Foundation, reprinted as pamphlet which described the Georgia Warm Springs Foundation as «A Centre for the Study and AfterTreatment of Poliomyelitis (Infantile Paralysis)», 1932, and distributed by the National Patients' Committee; and Ruhrah (September 1931), The Treatment of Polio in the Convales- 
«the process is reversed and the individual taught and encouraged to look after himself as far as is possible.» ${ }^{74}$ "The life is that of the ordinary resort type with its hotel and cottage facilities,» he explained, and «the 'resorters' are not looked on as sick people. ${ }^{75}$ It was not only muscle work that patients learnt, Ruhrah noted, but a rethinking of what it meant to be disabled. In one article printed as a separate pamphlet by the National Patients Committee, Ruhrah drew on his double perspective as a disabled man and a medical practitioner, suggesting that at Warm Springs «the 'Polio' learns that while it is all right to be an A.B. (able-bodied) there are many indeed who are far more handicapped than by a few muscles which will not function properly.» ${ }^{76}$

The community of activists at Warm Springs was part of a broader, nascent disability rights movement. In 1935 a group of disabled men and women in New York City protested discriminatory government policies, and organized themselves into the League of the Physically Handicapped. Defining disability as a part of an adult's experience, the League marched with signs that that read «We Don't Want Tin Cups We Want Jobs,» mocking the piteous images of the disabled typically promoted by charities and some New Deal agencies. ${ }^{77}$

The class allegiances of most Warm Springs guests were worlds away from the League of the Physically Handicapped, and the League was never discussed in the pages of the Polio Chronicle. But there was clearly some awareness at Warm Springs of a broader disability rights movement. In the same year that the League was established, Warm Springs manager Arthur Carpenter, one of the early organizers of the National Patients Committee, boldly redefined the Warm Springs Foundation's mission. Carpenter had been an advertising executive at Parents Magazine who had come to Warm Springs in 1928 and become part of Roosevelt's circle of friends. ${ }^{78}$ In a letter to the editor of $J A M A$ he argued that the Warm Springs Foundation should initiate a «comprehensive campaign» oriented around those disabled by polio. ${ }^{79}$ This national

cent Stage, Polio Chronicle, where he warned that many patients in the acute stage «are neglected» resulting in «horrible contractions and deformities».

74 See Ruhrah (1932) and Ruhrah (September 1931).

75 RUHRAH, Polio, p. 945.

76 RuhraH (1932). On «A.B». «an able-bodied person», see Anon. (January 1934), Glossary From Warm Springs, Polio Chronicle.

77 Longmore, P.K. and Goldberger, D. (2000), The League of the Physically Handicapped and the Great Depression: A Case Study in the New Disability History, Journal of American History, 87, pp. 888-922.

78 WALKER (1953), pp. 144-147; GOULD (1960), pp. 173-174.

79 (1935), Arthur Carpenter to the Editor, JAMA, 105, p. 1932. 
movement would raise the «general standard» of medical care and hospital facilities, and improve «specialized education training» so those with a «residual handicap» might «hold a useful place in life and ... become economically independent.» «Of equal importance,» wrote Carpenter, was educating employers «to the philosophy of giving an equal opportunity ... to those who have visible handicaps (orthopedic cripples), $\gg$ in order to counter the frequent «almost automatic ruling out of consideration of persons who use crutches or braces. $\|^{80}$

«A self-respecting person with the crippling handicap asks or wants no pity,» this disabled activist explained, turning to a metaphor resonant for wealthy adults. In reality a «polio» was just like a golfer «who has to accept a handicap to play in a foursome.» The «truth is,» Carpenter pointed out, every member of any golf foursome «has some kind of a handicap, if not the one on his score.» The «crippled» person «often has to face an unreasonable prejudice, solely because his handicap is visible. $\rangle^{81}$ Thus, this movement was to include consciousness-raising of fellow disabled adults; the education of employers, teachers and others who directed institutions where the disabled were denied access, learning, jobs, or respect; and a pointed criticism of the directors of medical and rehabilitation centers where disabled children and adults were neglected, facilities were poor, and staff were few and poorly trained.

Calling themselves «polios,» a term that did not have widespread currency until the 1950s, they hoped that Warm Springs' high profile would help the center become a potent weapon in the battle against prejudice and a key to raising public awareness of the inadequate medical care and facilities available for most disabled people elsewhere.

\section{THE POLITICS OF PLAY}

In a unique role reversal, patients at Warm Springs treated their doctors and physical therapists more like servants or assistants than like the fierce, controlling professionals the disabled usually encountered in other rehabilitation institutions. At Warm Springs, according to a publicity pamphlet Roosevelt distributed in the late $1920 \mathrm{~s}$, doctors and nurses «do not wear uniforms» but «mingle freely with the patients. $\rangle^{82}$ Such power reversals were defused by frequent refe-

80 Ibidem.

81 Ibidem.

82 «Hydrotherapeutic Center» pamphlet [c.1928] quoted in GALLAGHER (1985), p. 
rences to the special «spirit» of Warm Springs, which valued psychological healing and morale building; but implicit even in these vague terms was a comment on the ways disabled adults were usually treated outside this center.

Even more striking was the center's emphasis on play. Since the 1870s resort-like sanatoria, modeled on German health spas, had been built for affluent patients with tuberculosis and other ailments to provide an alternative to state-run institutions. Sanatorium rehabilitation was usually mixed with a moralistic discipline that discouraged frivolous pastimes like card playing. ${ }^{83}$ By the 1920s and 1930s, as Sheila Rothman has shown, private sanatoria were organized more like «exercises in charity» than «spas for the wealthy,» and patients sometimes saw them as «a waiting room for death.» Extensive rule books codified the distance between staff and patients, and the tubercular patients often felt humiliated and controlled even as they struggled to create communities where friendship and sexual expression was possible. ${ }^{84}$

The Warm Springs atmosphere provided a deliberate counterbalance to what one patient characterized as the «institutional» and «oppressively 'organized. "» 85 There was a «regular poker game which floated from cottage to cottage,» which Roosevelt sometimes joined when he visited the center. ${ }^{86}$ There were vaudeville shows and other entertainers from the region's cities, «dancers, acrobats, black face comedy, marionettes and singers.» ${ }^{87}$ There were also "glimpses» of «the great and near-great» when Roosevelt's friends and allies came to visit, including in 1933 Senator Robert Lafollette, Bernard Baruch, and British ambassador Sir Ronald Lindsay. 88

With a conscious commitment to the adult cultural world, movies were not «educational» but for entertainment. ${ }^{89}$ While the Polio Chronicle, its editors

51; New York Times (January 5, 1930), cited in GALLAGHER (1985), p. 52. This «hydrotherapeutic center», was neither a «hospital» nor «sanitarium» but «a year-round health resort for persons suffering from the loss of muscle control that follows infantile paralysis». see GOULD (1960), pp. 135-145, 161-162.

83 CAYlefF, S.E. (1987), Wash and Be Healed: The Water-Cure Movement and Women's Health, Philadelphia, Temple University Press; FeLDBERG (1995), pp. 52-53, 90-93.

84 Rothman S.M. (1994), Living in the Shadow of Death: Tuberculosis and the Social Experience of Illness in American History, New York, Basic, pp. 226-227, 231.

85 DonNelly (June 1932).

86 See Roosevelt, Shalett (1959), p. 194.

87 Anon. (February 1933), Interesting Events at Warm Springs, The Polio Chronicle.

88 Ibidem.

89 Anon. (July 1933), In the Spirit of 1933: The Georgia Warm Springs Foundation Looks Forward, Polio Chronicle. 
reflected, was «not a gossip sheet» it did intend to print «more of the humorous side of polio» for «the funny incidents and accidents are a part of our attitude toward polio ... [and] closely allied to our Crusade. $\rangle^{90}$ Reinforcing the sense of community was the development of distinctive customs and slang, including the term «polio» for the disease widely known as infantile paralysis, and «parals» and «polios» for disabled polio survivors. ${ }^{91}$ Instead of «the jaw-breaking Anterior Poliomyelitis,» one patient argued, «there is something jolly about the brief Polio. It sounds like a game, and it is played like a game at Warm Springs. With every rule of the true sportsman.» ${ }^{92}$

The cultivated patient-staff equality also fostered an «emotionally charged atmosphere,» invigorated by the «Georgia moon» and blooming magnolias. There were romances between patients and patients, push boys and patients, and therapists and patients. Not only was the water of the pools «tropically blue and caressing to the touch,» but the hydrotherapeutic sessions were clearly sexualized. $»^{93}$ One patient whose physical therapist was «a beautiful, tawny young woman with whom I immediately fell in love,» described his sessions with her in a bathing suit as «the nearest thing to making love that I had known for some time. $\rangle^{94}$ And sometimes there were marriages. Peabody College graduate Mary Hudson Veeder worked at Warm Springs first as a swimming instructor, then retrained as a physical therapist, and married one of the patients, who became a local journalist. ${ }^{95}$

\section{DiSABLED EMPLOYMENT DURING THE GREAT DEPRESSION}

Polio survivors without significant family resources may have hoped that the rehabilitative skills they learned at Warm Springs would bring them eco-

90 Editorial (April 1933), Gospel or Gossip, The Polio Chronicle.

91 On this «cheerful slang» see DE KRUIF, P. (February 1934), Forward From Polio, Ladies Home Journal, 51, p. 10. See also Anon. (January 1934), Glossary From Warm Springs, Polio Chronicle.

92 DONNELLY (June 1932).

93 Ibidem.

94 Plagemann (1990), p. 168; Donnelly (June 1932); Walker (1953), p. 155; GALLAGHER (1985), p. 57. See «third party» defined as «Warm Springsee [sic] for chaperon», Anon. (January 1934), Glossary From Warm Springs, Polio Chronicle; Do polios like riding in the moonlight, or, do they?; Anon. (January 1934), Bubbles From the Springs: High Spots of a Full Month, Polio Chronicle.

95 GOULD (1995). 
nomic independence, and the Polio_Chronicle eagerly reported success stories. Edwin Hicks was delighted to find that he was «making more use of a correspondence course in accounting that I took while at Warm Springs than I am of all my college work.» Another man coached high school students, including disabled pupils unable to attend school. A woman in Kansas worked as a secretary and one in Indiana painted greeting cards. One survivor worked as a pianist, another as a cartoonist, and others made their living writing short stories and selling magazine subscriptions. ${ }^{96}$ One young man established a successful greeting card business, and another became an insurance salesmen and used his own experience with disability insurance while he was a patient at Warm Springs «as effective sales talk to his prospects.»" ${ }^{97}$

The hope that Warm Springs would become an activist center for national disability rights was invigorated when Roosevelt was elected President in 1932. More than sixty Warm Springs patients and guests attended Roosevelt's inauguration in Washington. The group traveled on the «Warm Springs Special» and when it arrived in D.C. a special arrangement ensured that the train cars were "shunted into an area devoid of ladders and steps. ${ }^{98}$ The group had tea at the White House and, as one man exalted, «We knew that our 'Polio Crusader Number One' would never fail. What heights now could we not aspire to! $\gg{ }^{99}$

But as the Great Depression deepened, employer discrimination already common in earlier decades had harsher implications. A pessimistic former patient, who described himself as «a member of the crutch brigade,» reminded his peers that his own inability to find an accounting job was the result of the worsening economic situation, where «the employer's reaction is the obvious one with able-bodied unemployed applying for every job. 'Why experiment?'» To counter the "prejudice against employment of the handicapped,» he urged disabled adults become their «own employers,» suggesting that «the handicapped person» would find the public «kinder» than most ablebodied employers.»100

That a polio survivor had been elected president should, the Polio Chronicle's editor argued, «make it easier for parals to get jobs.» «His accomplishment forms an important link in the long chain of evidence that some day will

96 Townsend, G.K. (October, 1933), What Is Impossible?, Polio Chronicle.

97 Roosevelt, F.D. (1940), Foreword. In Anon., [Annual Report] Georgia Warm Springs Foundation.

98 BotTs, F. (April 1933), Inauguration Day!, The Polio Chronicle.

99 Ibidem.

100 Anon. (January 1934), Preparation Vs. Prejudice, Polio Chronicle. 
convince the business man of this country that a paral can handle a job as competently as any man.» ${ }^{101}$ The Polio Chronicle also devoted much space to combating the notion that disabled workers were a poor risk. One issue was full of an analysis of the Western Electric Company's analysis of employees with «vocational defects,» who were found to have fewer accidents, fewer absences on account of sickness, and in many cases to be «exceptionally outstanding in production.» ${ }^{102}$ "The experiment described is one of the most heartening significance to physically handicapped people,» the editors concluded, acknowledging regretfully that «the darkness of our general industrial picture must obscure and delay the logical development of a policy that combines social justice with good business practice.» ${ }^{103}$ Employers «should be and are gradually being educated to the idea of employing handicapped persons.» There was «no proof» to the frequent objection that «the disabled man is more apt to be injured while on the job» or that handicapped workers «cannot stand the pace of modern industry.» Indeed, disabled workers «average a longer time on one job than government reports show for the average worker.» «Given a job that takes into consideration his particular disability, it can safely be said that his employment is as economically sound as that of any other man. $\rangle^{104}$ Nor should it be a matter any longer of pressuring individual employers; new Congressional legislation had set aside funds to assist states «in providing a vocational rehabilitation service as part of their education system.» By 1933 forty-four states had a Vocational Rehabilitation Department in the state's board of education. ${ }^{105}$

But between the old view that disabled workers must develop a special determination to overcome discrimination and the activist hope of enlightening employers and countering discrimination by education, the Polio Chronicle's editorial balance consistently came to rest on the side of the work ethic. Many polio survivors, argued one Chronicle writer,

«are, or are studying to be, lawyers, accountants, teachers, writers, stenographers, or are in a multitude of success fields in a clerical or managerial capacity, and

101 Editorial (March 1933), Thank You, Mr. Roosevelt, The Polio Chronicle.

102 DieTZ, J.W. (March 1933), An Experiment with Vocationally Handicapped Employees, The Polio Chronicle.

103 DiETZ (March 1933), Editor's Note.

104 Editorial (February 1933), Employer Education, The Polio Chronicle.

105 Martin, L. (March 1933), Making the Best Of It, The Polio Chronicle. 
through all of their individual cases runs the one explanation for their present or possible success in their work — diligence!» ${ }^{106}$

\section{POLIO AS A NATIONAL CAMPAIGN, 1933-1937}

In 1933, when Franklin Roosevelt moved from the governor's mansion in Albany to the White House, his relations to Warm Springs and the Warm Springs Foundation were newly problematized. Even before he was castigated by his enemies as "that man in the White House,» there were growing rumors that Warm Springs was a moneymaking scam for Roosevelt personally and a corrupt part of the Democratic Party's system of political patronage. While polio remained Roosevelt's «disease» -in the sense that he became the nation's most famous survivor- Roosevelt's advisors decided to move polio fund-raising away from its focus on the patients at Warm Springs to a nationwide network of charity dances scheduled around the new president's birthday at the end of January. ${ }^{107}$ The idea of these Birthday Balls was first proposed at a meeting between members of the National Patients Committee and the Warm Springs Foundation trustees to plan fund-raising strategies. ${ }^{108}$ Gradually, control of this campaign was taken away from the Warm Springs group, to be defined and coordinated by the White House. 109

In January 1934 there were six thousand charity balls («dance so that others may walk») ranging from a \$25-a-head affair at New York's Waldorf Hotel to a dance organized by hospital workers at a state mental hospital. ${ }^{110}$ There were two balls held in Warm Springs: one attended local able-bodied residents of the town and the other by patients and staff at the center. ${ }^{111}$ This segregation was prescient. Although Warm Springs activists sought to hold onto the new national energy and reclaim it as a force for disabled power, the

106 Ibidem.

107 LiPPMAN (1977), pp. 203-204. They relied on such shady business magnates as Henry Doherty, head of a utilities holding company, accused of stocks manipulation and tax evasion. Money from these Birthday Balls was to be used to establish a permanent endowment for the Warm Springs Foundation.

108 See Sills D.L. (1957), The Volunteers: Means and End in a National Organization, Glencoe, Ill., Free Press, pp. 42-43; PAUL (1971), pp. 305-307. The funds were to be used to create a permanent endowment for the Warm Springs Foundation.

109 LippMAn (1977), pp. 203-204.

110 CoHn, V. (1955), Four Billion Dimes, Minneapolis, p. 43; GoUld (1995), pp. 60-61.

111 LIPPMAN (1977), pp. 204-205. 
Birthday Ball campaign, which became an established annual fund-raising event during Roosevelt's first term, linked polio care to welfare and charity, the traditional responsibilities of the able-bodied. ${ }^{112}$ Instead of adults seeking respect and employment, the campaigns featured posters and cartoons of a child leaning on a crutch.

Roosevelt's enemies simply added the Birthday Ball celebrations to their list of targets. In what was called the «Whispering Campaign,» it was rumored that polio had left the president a drug addict, sexually impotent, incontinent, and a helpless cripple, so erratic that he required a straight-jacket. ${ }^{113}$ During a radio speech in April 1935 Georgia governor Eugene Talmadge claimed that the greatest calamity was that Roosevelt could not «walk round and hunt up people to talk to,» implying that being bound to a wheelchair left him vulnerable to the manipulation of a select group of advisors. ${ }^{114}$ During the 1936 re-election campaign political pundit George Gundelfinger gave the president's disability an even sharper political edge with his remark that compassionate America «believes in doing all it can for cripples - but its compassion need not go quite so far as to make them President of the United States.» ${ }^{115}$

Such comments reminded Roosevelt and his advisors of the dangers of having a major political figure seen as visibly disabled or too close to other visibly disabled adults, especially those vocal patients at Warm Springs. Rather, Roosevelt's public image must be even more forcefully defined as that of a courageous man who had conquered polio. This was all the more important because the eugenics movement had powerfully linked visible physical disabilities to mental disability. Finally, with the gendered connotations of weakness and emasculation, so deadly in political life, a disabled man was widely

112 For a broader history of the experiences and discrimination faced by most disabled Americans see. LONGMORE, UMANSKY (2001).

113 Wolfskill, G., Hudson, J.A. (1969), All but the People: Franklin D. Roosevelt and His Critics 1933-1939, London, Macmillan, pp. 4-16; see also LIPPMAN (1977), pp. 64-67, 187-198.

114 WOLFSKILL, HUDSON (1969), pp. 14, 104. Georgia governor Eugene Talmadge's remark that the Warm Springs Foundation was «a racket, being disguised under the name of charity, by the President of the United States» was widely reported, and he later breached the niceties of mainstream politics by calling Roosevelt «that cripple in the White House».

115 WOLFSKILL, HUDSON (1969), p. 13. In 1935 Gundelfinger also warned of the «bug of Roman Catholicism» that controlled Roosevelt's mind like polio germs controlled his body, and perhaps «they are one and the same thing». For more on the Brown Scares of the 1930s and 1940s see RiBufFo, L.P. (1983), The Old Christian Right: The Protestant Far Right From the Great Depression to the Cold War, Philadelphia, Temple University Press, pp. 178-224. 
considered unfit for responsible office and political power. ${ }^{116}$ Even with the deep public support for Roosevelt as a president and leader, his advisors clearly could not imagine responding to these rumors by defending disabled citizenship and equality. Indeed, Roosevelt supporters retaliated against these attacks in like manner. Thus, using ad hominem, eugenic language, New York Congressman John O'Connor smeared Talmadge as being «unfit to be elected a dogcatcher, let alone Governor.»»117

Roosevelt's political fortunes began to falter, and polio fund-raising suffered. In January 1936, despite the introduction of movie stars Ginger Rogers, Jean Harlow and Robert Taylor at the White House, the Birthday Ball celebrations did not bring in as much money as the year before. ${ }^{118}$ Between February and July 1937, frustrated by a Supreme Court which was «crippling» his New Deal administration by finding its legislation unconstitutional, Roosevelt boldly proposed adding more justices to the «nine old men» on the court. ${ }^{119}$ With the uproar this proposal caused, and its disastrous political ramifications, Roosevelt distanced himself even further from the organization of polio fund-raising. Some commentators have seen this move as an effort to protect the fund-raising enterprise, but in the context of this history of polio activism we need also to see it as a maneuver to protect his political reputation. ${ }^{120}$

In September 1937, Roosevelt announced the formation of a new national Foundation for Infantile Paralysis (the word «national» was initially not capitalized). He would not «hold any official position in it,» and its director would be his former law partner and discreet political advisor Basil O'Connor, who was already the nominal head of the Warm Springs Foundation. ${ }^{121}$ "The time has now arrived,» Roosevelt announced, "when the whole attack on this plague should be led and directed, though not controlled, by one national body.» The new organization would provide training for medical professionals in order to eliminate «the use of antiquated treatment, or downright neglect of any treatment» which were «the causes of thousands of crippled, twisted, powerless bodies.» The physician was «the front line fighter of sickness,» but the new

116 WiLSON, D.J. (1998), A Crippled Manhood: Infantile Paralysis and the Constructing of Masculinity, Medical Humanities Review, 12, pp. 9-28.

117 WOLFSKILL, HUDSON (1969), pp. 14, 104; for an excellent analysis of this process see HOUCK and KIEWE (2003).

118 CoHn (1955), p. 44. The amount was $\$ 787.526$.

119 WOLFSKILL, HudSON (1969), pp. 259-270.

120 LIPPMAN (1977).

121 LipPMAN (1977), pp. 208. 
Foundation would also «develop every medical possibility of enabling those so afflicted to become economically independent in their local communities.» While the new national Foundation would «direct and coordinate the fight against this disease in all its phases,» the Warm Springs Foundation would «concentrate its efforts directly on the medical problems involved» in treating polio's aftereffects. ${ }^{122}$

While increasing numbers of adolescents and adults were joining the ranks of the paralytic victims of polio epidemics, the Foundation's publicity campaigns - invigorated with the catchy name March of Dimes - remade the polio survivor in the image of the hopeful child, attractive and eager to walk again. Pictures featured children perched on crutches and hunched in wheelchairs, silent and smiling. A nationally syndicated cartoon for one campaign showed a little boy kneeling by his bed and praying «may God bless everyone who is helping me get well, so I can some day help other children get well.» A sign on the crutches next to him read «Fight Infantile Paralysis - Join the March of Dimes.»123

Here, rehabilitation meant adjustment to physical limitations and not integration into society, a striving for normality and not an open realism about physical difference. This presentation of disability drew on older visual traditions of disease fund-raising and social reform: the pathetic, impoverished child at the center of Lewis Hine's photographs in the 1890s calling for viewers to demand the end to industrial exploitation and child labor; the adorable child Crusaders at the heart of the National Tuberculosis Association's campaigns in the 1910s and 20s; and the Depression era photographs that marked the ravages of hunger and economy instability in the faces and bodies of children. ${ }^{124}$ In 1946 the March of Dimes formally instituted its Poster Child campaigns, which created polio child-celebrities who were featured in posters and other propaganda. ${ }^{125}$ Children were good for fund-raising, but at the political level they also signalled the shift back to the treatment of the disabled as the objects of sentimental publicity, and a renewed strategy of disregard for the disabled as agents of policy and change.

122 Roosevelt (1940). On the protests from local communities during 1938 that led the National Foundation to add local Chapters see SILLS (1951), p. 44-46.

123 Quoted in Bradshaw, N. (Winter 1989), Polio in Kentucky: From Birthday Balls to the Breakthrough, Register of the Kentucky Historical Society, 87, pp. 31-32.

124 LONGMORE and GOLDBERGER (2000).

125 Smith, J.S. (1990), Patenting the Sun: Polio and the Salk Vaccine, New York, William Morrow \& Co. 
A prominent omission from this centralized national agenda was any mention of the «rehabilitation» into society of those disabled by polio. Now, rehabilitation would mean only aftercare, defined in medical terms as a return to a normal, functioning body. This was worlds away from the special environment of Warm Springs and the demands of the National Patients Committee. ${ }^{126}$ And indeed, by this time the Polio Chronicle had ceased publication, the League for the Physically Handicapped had dissolved, and disabled activism was in retreat. Two significant changes led to the decline of Warm Springs activism by the late 1930s. Both were the result of cultural forces, signs that the activist Polio Crusaders had lost the cultural war they had embarked on. The first was the remaking of Warm Springs into a medicalized therapeutic center. The second was the rise of polio research as a way to depoliticize both Warm Springs and polio fund-raising. As a matter of policy, these new projects characterized disabled activists as narcissistic, focused on with their own physical and mental rehabilitation, and not on the more important issues of disease prevention and scientific investigation. The new National Foundation funded medical training to improve quality of care by doctors, nurses, therapists; it covered patients' expenses for hospital bills and further treatment; it improved access to care, to new equipment, and to treatment facilities. All these issues had been raised by the National Patients Committee. But the new Foundation developed no policies for employing the disabled or battling discrimination, which the Committee had seen as of equal importance.

The growing medicalization of Warm Springs was partly the result of new admission policies which did not reflect the broader demographic shift in polio cases. In the polio epidemics of the 1930s and 40s the age of polio cases gradually increased. But the patients admitted to Warm Springs did not reflect this epidemiological pattern: they were getting younger. In 1929 around 75\% were teenagers or adults; by 1940 only $60 \%$ were over fifteen. ${ }^{127}$ The higher numbers of children changed the atmosphere of Warm Springs. Adult romances were still possible, but educational training and formal rehabilitation, with their consequent regimentation of daily life, were made far more central. By 1939 there were a new medical building and a school house, expanded facili-

126 LIPPMAN (1977), pp. 208. Warm Springs, however, continued to be Roosevelt's private, social refuge.

127 Hubbard, L.W. (1929), Annual Report of the Surgeon-Chief, George Warm Springs Foundation, Incorporated (1929), disabilitymuseum.org/lib/docs/2166.htm (03/04/2009); RoosEVELT (1940). 
ties for occupational therapy (including metal working, loom weaving, sewing and pottery) and new dormitories for both adults and children. ${ }^{128}$ When the Polio Crusade activists had spoken of «rehabilitation,» they had given it a double meaning: not only medical and physiological, but social and political. But expanding numbers of professionally training physical and occupational therapists helped to strip the term of the latter meaning. ${ }^{129}$

Thus, the 1940 annual report explained that Warm Springs was «essentially a medical institution» where «medical care and treatment is paramount and takes precedence over all other factors,» but that such therapy was most effective «when supplemented by high morale» and a physical environment «totally different from that usually associated with an institution of this kind. $\gg{ }^{130}$ This commitment notwithstanding, the numbers and professional stance of the center's physical therapists was stiffened by constant criticism of the resort's famous combination of joyous rehabilitative therapy and socializing. Such a frivolous atmosphere could undermine its therapeutic aims, according Los Angeles orthopedist Charles Lowman. While «country-wide interest in this form of treatment was aroused by the development at the George Warm Springs,» he admitted, «the discipline and regulation of thoughtful, concentrated work in a careful sequence can be wholly upset if a play element of general activities be indulged in during the same period.» ${ }^{131}$ In a series of articles in medical journals he criticized «the confusion of the recreational and reeducation features,» explaining that «technically, it is not sound clinical or physiologic treatment to mix the two as is done in some pools,» and compared «unsupervised» therapy designed only «on a play basis of free response to emotional impulses and desires» to «a carefully laid out plan of graded, supervised muscle training.» ${ }^{132}$ In response to such attacks

128 Roosevelt (1940).

129 For a discussion of the double meaning of rehabilitation, see BYROM, B., A Pupil and a Patient: Hospital-Schools in Progressive America. In Longmore, P.K. and UMANSKY, L. (eds.) (2001), The New Disability History: American Perspectives, Albany, New York University Press, pp. 133156; and for a broader respective see Roger Cooter / and Geitzer? COOTER, R. (1993), Surgery and Society in Peace and War. Orthopaedics and the Organization of Modern Medicine, 1880-1948, Houndmills, The Macmillan Press; Gritzer, G., ARLUKE, A. (1985), The Making of Rehabilitation: A Political Economy of Medical Specialization, 1890-1980, Berkeley, University of California Press.

130 RoOSEVELT (1940).

131 Lowman, C.L. (Jan 1932), Physiotherapy in the Water, American Journal of Nursing, 32 , pp. 9, 12.

132 Lowman, C.L. (Oct 10, 1931), Underwater Gymnastics, JAMA, 97, pp. 1074-1076. «Many laymen believe that the influence on paralytic and other ailments is due to some in- 
Warm Springs set up a training school for physical therapists in 1941, which, National Foundation publicity argued, would «serve as a research laboratory where new techniques can be developed.» ${ }^{133}$

Fiscally, the National Foundation's polio were oriented away from Warm Springs. Now the funds were to be divided $70 \%$ for care and treatment in the community where they had originated, and $30 \%$ for research with grant recipients to be determined by a special committee of physicians and scientists. ${ }^{134}$ Despite this emphasis towards improving polio care in local communities, the Warm Springs center continued to be seen as a last hope by desperate families. Thanks to its Patients Aid Fund, the work of its wealthier alumni, Warm Springs was regularly praised for its non-exclusive admissions policies; estimates were that around one third of the patients paid full price, one third paid part and one third paid nothing. Desperate applicants used every political and personal connection they had to get in, a situation worsened because chronic disability always held out the hope for improvement. 135

From the beginning activists patients at Warm Springs had seen research as a crucial element in the fight against polio, and it had been part of the National Patients Committee's agenda. ${ }^{136}$ Now that raising money for polio had been reconceived as a national campaign best run by professionals, committees of experts defined the terms and direction of research and health care policy to the exclusion of the disability rights issues. In a stereotypical picture of the selfish disabled caring only about therapy, popular science writer Paul de Kruif frequently told his version of the story of why the National Foundation had become involved in funding research by quoting his own provocative questions to Warm Springs manager Arthur Carpenter:

«Why do you use all that dough to dip cripples in warm water? That doesn't cure them, any more than it cured you or the President. Why don't you ask the Pre-

\footnotetext{
herent potency or active principle in the water... it is common sales talk in advertising sanatoriums and resorts at which hot springs exist to claim that the efficacy of treatment by or in these waters is due to some active factor in them. The value of underwater gymnastics, however, is one of physics and not of chemistry», p. 1075.

133 RoOSEVELT (1940).

134 LIPPMAN (1977), pp. 207-208.

135 Gould (1995), p. 61.

136 On the Warm Springs Foundation's agenda involving «research in prevention and immunization», see Carpenter to Editor (1935).
} 
sident to devote a part of that big dough to research on polio prevention? Nobody knows a thing about that.» ${ }^{137}$

Disability rights vanished from public discourse.

The new Foundation's intent was to demonstrate a broad, national vision of polio control. An emphasis on funding research may also been intended to ameliorate protests by the many already existing crippled children's societies, some established decades earlier, whose directors were unhappy with the transformation from a Warm Springs Foundation to a national polio philanthropy. Officials wrote to Basil O'Connor protesting that they saw no need for such a group and tried to use political pressure to limit its scope and power. ${ }^{138}$

It also was intended to distract attention from other, political problems that Warm Springs' national prominence had raised, especially the issue of its racial segregation. During the 1936 re-election campaign Republicans tried to regain the black vote by pointing out that Warm Springs did not admit black patients. Roosevelt's political reputation as a supporter of racial pluralism and his unofficial Black Cabinet explain the letter from an Ohio woman enclosing $\$ 12$ for the «Infantile Paralysis Fund» and asking the president to issue a statement «contradicting [the] impression among colored people that Negroes are not permitted to enter Warm Springs Foundation for treatment.. ${ }^{139}$ In 1939 the National Foundation announcing it would be opening a new facility at the all-black Tuskegee Institute with equivalent equipment and staff. ${ }^{140}$

\section{THE CRUSADE ENDS}

The Warm Springs Polio Crusade had been designed by its subjects. By the mid-1930s the disabled Warm Springs community had developed several traditions, including an annual Founder's Day Thanksgiving dinner which Roosevelt usually attended. During the banquet someone recounted the histo-

137 De KruIF, P. (1962), Sweeping Wind: A Memoir, New York, Harcourt, Brace \& World, pp. 177-178; on de Kruif see SUMMERS, W.C. (1998), Microbe Hunters Revisited, International Microbiology, 1, pp. 65-68.

138 See for example Morris Fishbein to Basil O’Connor, October 18, 1939, Public Relations Files: Fishbein/1938, March of Dimes Archives, White Plains, New York.

139 Rosa E. Hayes [Columbus Ohio] to President, January 28, [1939], letter referred to Keith Morgan, Comm. Celeb. President's Birthday Files, FDR-PPF-4885 Cross Ref.s (19391940), Franklin Delano Roosevelt Papers, Hyde Park, New York.

140 GOULD (1995). 
ry of Warm Springs, there was singing, piano playing, humorous sketches, telegrams read, and a roll call by states. ${ }^{141}$ Such events brought the community together, and yet also reinforced its ambiguity. Through its early history, Warm Springs had somewhat awkwardly combined roles as resort, refuge and rehabilitative center. Were its members guests or patients? Such ambiguity had permeated the Polio Crusade as well, as its disability activists tried to construct an image of disability that allowed adults with visible impairments to live and work in mainstream America. The particular crusade oriented around Warm Springs ended with the rise of the March of Dimes, but polio survivors continued to fight social and economic discrimination at their homes, schools and workplaces. The emergence of the Independent Living Movement in the 1960s was spearheaded by a new generation of adult polio survivors, who were children just as Warm Springs oriented its rehabilitative efforts around child patients. Perhaps the legacy of activism can be traced to the inspiring example of Warm Springs as a «Polio's Paradise.»

Fecha de recepción: 18 de septiembre de 2008.

Fecha de aceptación: 24 de noviembre de 2008.

141 Anon. (December 1932), Headliners of the Month, Polio Chronicle. 